\title{
ANTROPOMETRI SENDI PERGELANGAN KAKI ETNIS MINANGKABAU
}

\author{
Hafni Marsil ${ }^{1}$, Rizki Rahmadian¹, Sylvia Rachman², Erkadius ${ }^{3}$
}

\begin{abstract}
Abstrak
Penelitian ini bertujuan mengukur antropometri sendi pergelangan kaki etnis Minangkabau. Penelitian cross sectional dilakukan pada 50 orang mahasiswa kedokteran etnis Minangkabau berusia 21-25 tahun di lingkungan RS. dr. M Djamil Padang. Dilakukan pemeriksaan ROM, rontgen ankle proyeksi anteroposterior, lateral dan mortise. Hasil penelitian didapatkan ROM plantarfleksi $48,92^{\circ} \pm 5,82^{\circ}$, ROM dorsofleksi $31,30^{\circ} \pm 4,07^{0}$, inversi $10,32^{\circ} \pm 2,28^{\circ}$, eversi $5,94^{\circ} \pm 1,20^{\circ}$, talocrural angel anteroposterior $76,53^{\circ} \pm 2,53^{\circ}$ dan mortise $77,38^{\circ} \pm 2,27^{\circ}$, tibiofibular

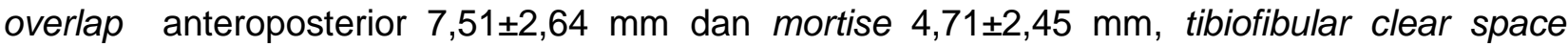
anteroposterior $3,6 \pm 1,18 \mathrm{~mm}$ dan mortise $3,85 \pm 1,09 \mathrm{~mm}$, talar tilt anteroposterior $0,14^{0} \pm 0,10^{0}$ dan mortise $0,19^{\circ} \pm 0,15^{\circ}$, medial malleolar length anteroposterior $13,88 \pm 1,99 \mathrm{~mm}$ dan mortise $14,03 \pm 1,69 \mathrm{~mm}$, lateral malleolar length anteroposterior $25,71 \pm 2,83 \mathrm{~mm}$ dan mortise $26,70 \pm 3,40$ $\mathrm{mm}$, johnson angle anteroposterior $87,77^{\circ} \pm 1,71^{\circ}$ dan mortise $87,57^{\circ} \pm 1,84^{\circ}$, medial clear space $2,97 \pm 0,75 \mathrm{~mm}$, anteroposterior inclination angle $7,47^{\circ} \pm 2,70^{\circ}$, anterior distal tibial angle $82,53^{\circ} \pm$ $2,70^{\circ}$, dan anteroposterior gap 3,50 $\pm 1,43 \mathrm{~mm}$. Terdapat perbedaan ukuran antropometri sendi pergelangan kaki mahasiswa kedokteran beretnis Minangkabau di lingkungan RS. Dr. M. Djamil Padang dengan kepustakaan, namun masih dalam rentang normal.
\end{abstract}

Kata kunci: antropometri, pergelangan kaki, Minangkabau

\begin{abstract}
This study aimed to measure anthropometric of ankle joint of Minangkabau ethnic group. Cross sectional study has been done in 50 Minangkabau ethnic medical students, aged 21-25 years in RSUP. Dr. M Djamil Padang. ROM, anteroposterior, lateral, and mortise $X$-ray projections of ankle were examined. ROM plantarflexion was $48.92^{\circ} \pm 5.82^{\circ}$, ROM dorsiflexion was $4.07^{\circ} \pm 31.30^{\circ}$, inversion was $10.32^{\circ} \pm 2.28^{\circ}$, eversion was $5.94^{\circ} \pm 1.20^{\circ}$, talocrural angel anteroposterior was $76.53^{\circ} \pm 2.53^{\circ}$ and mortise was $77.38^{\circ} \pm 2.27^{\circ}$, tibiofibular overlapp anteroposterior was $7.51 \pm 2,64 \mathrm{~mm}$ and mortise was $4.71 \pm 2,45 \mathrm{~mm}$, tibiofibular clear space anteroposterior was $3.6 \pm 1.18 \mathrm{~mm}$ and mortise was $3.85 \pm 1.09 \mathrm{~mm}$, talar tilt anteroposterior was $0.14^{\circ} \pm 0.10^{\circ}$ and mortise was $0.19^{\circ} \pm 0.15^{\circ}$, medial malleolar length anteroposterior was $13.88 \pm$ $1,99 \mathrm{~mm}$ and mortise was $14.03 \pm 1,69 \mathrm{~mm}$, lateral length malleolar anteroposterior was $25.71 \pm 2,83 \mathrm{~mm}$ and mortise was $26.70 \pm 3,40 \mathrm{~mm}$, johnson angle anteroposterior was $87.77^{\circ} \pm$

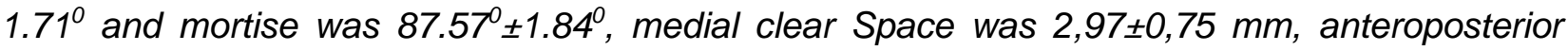
Inclination Angle was $7.47^{\circ} \pm 2.70^{\circ}$, anterior distal tibial Angle was $82.53^{\circ} \pm 2.70^{\circ}$ and anteroposterior gap was $3.50 \pm 1,43 \mathrm{~mm}$. There was a difference in antropometric size of the ankle joint between Minangkabau ethnic medical student in RSUP. Dr. M. Djamil Padang and literature, but still within the normal range.
\end{abstract}

Keyword: anthropometry, ankle joint, Minangkabau

Afiliasi Penulis: 1. Bagian IImu Bedah FK Unand/ RSUP dr. M. Djamil Padang, 2. Bagian Radiologi FK Unand/ RSUP dr. M. Djamil Padang, 3. Bagian Fisiologi FK Unand, Korespondensi : Hafni Marsil, email : dr.pail@yahoo.co.uk, HP: 081363415107 


\section{PENDAHULUAN}

Antropometri adalah ilmu yang mempelajari pengukuran tubuh manusia guna merumuskan perbedaan ukuran pada tiap individu atau kelompok. IImu ini berkembang sejak abad ke-19. Istilah antropometri pertama kali diperkenalkan oleh Quetlet seorang ilmuan asal Belgia dalam bukunya Antrhopometrie. Pengukuran bagian tertentu dari tubuh manusia dapat dilakukan dengan berbagai cara dengan tujuan yang berbeda-beda, seperti pengukuran tinggi dan berat badan untuk melihat status gizi, identifikasi korban dalam ilmu forensik, membuat alat-alat yang ergonomis dalam bidang industri, dan pengukuran antropometri secara radiologis untuk membantu dalam menegakkan diagnosis, penilaian pre dan pasca operatif kasuskasus ortopedi yang memerlukan pembedahan. ${ }^{1,2}$

Sendi pergelangan kaki adalah daerah persendian antara tungkai bawah dan kaki. Sendi pergelangan kaki terdiri dari 3 persendian yang kompleks, yaitu sendi talokrural, sendi tibiofibular distal (sindesmosis tibiofibular) dan sendi subtalar (talokalkaneal). ${ }^{3,4}$ Sendi pergelangan kaki merupakan sendi yang menyokong berat badan dan penting dalam tahapan berjalan berupa gerakan plantarfleksi dan dorsofleksi. ${ }^{5}$

Ukuran antropometri tulang ditentukan oleh maturasi dan pertumbuhan tulang, yang dipengaruhi oleh faktor genetik, nutrisi, hormonal, dan lingkungan. Faktor genetik ini akan diturunkan sehingga masing-masing ras dan suku bangsa akan mempunyai ciri ukuran antropometrinya sendiri. ${ }^{2,6}$

Pada kasus-kasus orthopedi yang berhubungan dengan sendi perge- langan kaki, pemeriksaan radiologis sangat membantu dalam menegakkan diagnosis sehingga dapat memastikan terjadinya kelainan pada struktur tulang maupun jaringan lunak dari sendi pergelangan kaki. Pengukuran antropometri secara radiologis juga memegang peranan penting bagi keberhasilan tindakan operasi pada sendi pergelangan kaki. Nilai yang diperoleh dari pengukuran tersebut dapat memprediksi keberhasilan tindakan operasi melalui penilaian pre dan postoperatif. ${ }^{7}$ Pengukuran antropometri pergelangan kaki juga berguna untuk merancang implant dan prosthesis yang ergonomis. ${ }^{8}$

Penelitian Patil dkk terhadap antropometri sendi pergelangan kaki didapatkan tibiofibular clear space pada $x$-ray proyeksi anteroposterior (AP) adalah $2.4 \mathrm{~mm}$ dengan proyeksi mortise $4.5 \mathrm{~mm}$, tibiofibular overlap pada proyeksi AP $11.2 \mathrm{~mm}$ dengan proyeksi mortise $4.2 \mathrm{~mm}$, dan talocrural angle pada proyeksi AP $77.7 \mathrm{~mm}$ dengan proyeksi mortise $79.9 \mathrm{~mm}$. Patil dkk juga menemukan length of medial malleolus pada proyeksi AP $15.3 \mathrm{~mm}$ dengan proyeksi mortise $15.3 \mathrm{~mm}$ dan length of lateral malleolus pada proyeksi AP $27.35 \mathrm{~mm}$ dengan proyeksi mortise $26.5 \mathrm{~mm}^{8}$

Penelitian Goker dkk mendapatkan medial clear space 2,56 $\pm 0,50 \mathrm{~mm}$ pada sendi pergelangan kaki kanan dan $2,55 \pm 0,48 \mathrm{~mm}$ pada sendi pergelangan kaki kiri. Goker mendapatkan medial clear space pada laki-laki lebih lebar dibandingkan pada perempuan. ${ }^{9}$ Kwon dkk mendapatkan nilai normal anteroposterior inclination angle pada populasi Korea $8,2^{0} \pm 3,2^{0}$. Kwon dkk juga mendapatkan ukuran morfometri pergolangan kaki pada orang Korea lebih kecil 
dibandingkan dengan ukuran pada orang kulit putih. ${ }^{10}$ Begitu juga dengan penelitian yang dilakukan oleh Kuo dkk pada populasi ras Cina yang menemukan ukuran morfometri sendi pergelangan kaki lebih kecil dibandingkan dengan ukuran pada orang kulit putih. ${ }^{11}$

Range of motion (ROM) adalah rentang pergerakan yang dapat dilakukan oleh suatu atau sekelompok sendi. Pada sendi pergelangan kaki terdapat empat pergerakan sendi yaitu: dorsofleksi, plantarfleksi, eversi dan inversi. ROM dorsofleksi, plantarfleksi, eversi, dan inversi pada orang dewasa normal menurut American Academy of Orthopaedic Surgeon secara berurut adalah $20^{0}, 50^{\circ}, 5^{0}$ dan $5^{0} .{ }^{12}$

Sendi pergelangan kaki adalah sendi yang komplek, menerima beban tubuh dan penting dalam tahapan berjalan. Kelainan pada sendi ini harus direposisi seanatomis mungkin. Lebih lebarnya ankle mortise $1 \mathrm{~mm}$ menyebabkan berkurangnya luas kontak tibiotalar sebesar $42 \%$. Hal ini menyebabkan instabilitas sendi dan meningkatnya kejadian osteoartritis. Karena itu pemahaman tentang antropometri sendi pergelangan kaki sangat penting. ${ }^{9}$

Selama ini sudah terdapat nilainilai normal pemeriksaan radiologis sendi pergelangan kaki dari berbagai penelitian di dunia. Hal ini lazim digunakan sebagai pedoman untuk memperkirakan adanya kelainan pada sendi pergelangan kaki. Nilai-nilai tersebut merupakan hasil dari penelitian yang dilakukan di negara-negara barat dengan subjek penelitian terutama bangsa kulit putih, yang secara fisik berbeda dengan populasi lokal di Indonesia. Dengan demikian kurang dapat memberikan gambaran mengenai nilai-nilai normal pada po- pulasi lokal, sehingga data-data yang ada tidak dapat dijadikan nilai standar untuk populasi lokal di Indonesia.

Karena belum adanya data mengenai ukuran antropometri sendi pergelangan kaki pada etnis Minangkabau di dalam kepustakaan, maka peneliti bermaksud melakukan penelitian mengenai antropometri sendi pergelangan kaki pada etnis Minangkabau.

\section{METODE}

Penelitian cross sectional dilakukan terhadap 50 orang mahasiswa etnis Minangkabau di RSUP Dr. M Djamil Padang dan pengukuran radiologis dilakukan di Semen Padang Hospital dari Februari 2015 hingga April 2015. Subjek penelitian berusia 21-25 tahun, terdiri dari 25 orang laki-laki dan 25 orang perempuan. Pengambilan sampel dilakukan secara consecutive sampling. Setelah mengisi formulir persetujuan, maka dilakukan pengukuran ROM dan $x$ ray sendi pergelangan kaki kiri subjek penelitian. Kelayakan hasil $x$-ray diperiksa oleh observer radiologi. Batas-batas daerah yang akan diukur dinilai dari hasil $x$-ray secara komputerisasi dan dievaluasi oleh observer radiologi. Data deskriptif ditampilkan dalam bentuk mean dan standar deviasi. Perbedaan pengukuran antara pria dengan wanita diuji menggunakan t-test independen dengan derajat keperca-yaan 95\%. Hasil uji bermakna jika nilai $p<0,05$.

\section{HASIL DAN PEMBAHASAN}

Rerata ROM dorsofleksi mahasiswa kedokteran yang beretnis minangkabau adalah $31,30^{\circ} \pm 4,07^{0}$ dengan rentang $2^{0}-39^{\circ}$. Hasil ini lebih besar dari nilai yang ditetapkan oleh American 
Academy of Orthopaedic Surgeon dan American Medical Association yang mengatakan nilai ROM dorsofleksi dewasa normal adalah 200.12 Salah satu faktor yang mempengaruhi ROM adalah aktifitas dan latihan. Penelitian Johanson dkk menyimpulkan terdapat peningkatan ROM dorsofleksi setelah dilakukan latihan gastrocnemius stretching. ${ }^{13}$ Apakah lebih besarnya ROM dorsofleksi pada orang minangkabau mungkin disebabkan karena setiap harinya melaksanakan sholat? Dalam gerakan sholat pada saat sujud, sendi pergelangan kaki berada pada keadan dorsofleksi maksimal dan terjadi regangan pada otot gastrocnemius, sehingga latihan yang rutin dikerjakan setiap harinya ini menyebabkan orang minangkabau mempunyai ROM dorsofleksi yang lebih besar dibandingkan dengan bangsa kulit putih.

American Academy of Orthopaedic Surgeon mengatakan nilai ROM plantarfleksi dewasa normal adalah $50^{\circ}$. Hasil yang hampir sama didapatkan pada penelitian ini, dimana didapatkan rerata ROM plantarfleksi adalah $48,92^{\circ} \pm 5,82^{\circ}$. Penelitian yang dilakukan oleh Boone dan Azen didapatkan ROM plantarfleksi $56,2^{0} \pm 6,1^{0}$ (disitasi dari Norkin dan white). ${ }^{12}$

Pada penelitian ini didapatkan hasil ROM eversi $5,94^{\circ} \pm 1,20^{\circ}$, hasil ini hampir sama dengan American Academy of Orthopaedic Surgeon yang mendapatkan ROM eversi $5^{\circ}$. Penelitian Collete dkk di Australia mendapatkan nilai normal ROM eversi $8,3^{0} \pm 3,6^{0}$ (disitasi dari Norkin dan white, 2009). ${ }^{12}$

Nilai ROM inversi pada penelitian ini adalah $10,32^{0} \pm 2,28^{\circ}$, hasil ini lebih besar dari nilai inversi yang ditetapkan oleh American Academy of Orthopaedic Surgeon yang mengatakan nilai ROM inversi $5^{0}$. Penelitian Collete dkk di Australia mendapatkan nilai ROM inversi $15^{0} \pm 6,1^{0}$ (disitasi dari Norkin dan white, 2009). ${ }^{12}$

Pada penelitian ini tidak ditemukan perbedaan yang bermakna secara statistik nilai ROM dorsofleksi, plantarfleksi, eversi dan inversi antara pria dan wanita. Berbeda dengan penelitian Grimston dkk pada 120 subjek, mendapatkan wanita memiliki ROM sendi pergelangan kaki lebih besar dibandingkan pria. Hasil ini serupa dengan penelitian Bell dan Hoshizaki dimana ROM plantarfleksi dan dorsofleksi wanita lebih besar dari pria. Nigg berpendapat lebih besarnya nilai plantarfleksi pada wanita disebabkan kebiasaan wanita memakai sepatu high-heeled. Hasil penelitian ini berbeda dengan penelitian lainnya mungkin dikarenakan mahasiswa kedokteran wanita yang menjadi subjek penelitian jarang memakai sepatu highheeled sehingga tidak didapatkan berbedaan antara ROM wanita dan pria (disitasi dari Norkin dan white, 2009). ${ }^{12}$

Menurut Isman dan Inam talocrural angel berfungsi untuk melihat perubahan panjang fibula. ${ }^{14}$ Codi mengatakan talocrural angel harus dibandingkan dengan ekstremitas yang sehat, dan perbedaannya tidak boleh lebih dari $2^{0}$. Sedangkan Phillips berpendapat perbedaan lebih dari $5^{0}$ antara kiri dan kanan menandakan suatu keadaan yang abnormal (disitasi dari Magid et al., 1990). ${ }^{15}$ Pada penelitian ini didapatkan nilai talocrural angel pada proyeksi anteroposterior $76,53^{\circ} \pm 2,53^{\circ}$ dan pada proyeksi mortise $77,38^{\circ} \pm 2,27^{0}$, serta tidak terdapat perbedaan bermakna secara statistik antara pria dan wanita. Penelitian ini serupa dengan penelitian yang dilakukan Donna dkk di 
Amerika Serikat yang mendapatkan nilai $77^{0} \pm 4^{0}$ (disitasi dari Magid et al., 1990) ${ }^{15}$, dan Rolfe dkk yang mendapatkan hasil 78,50.16 Pada penelitian yang lain di India, Patil dkk mendapatkan nilai talocrural angel pada proyeksi anteroposterior $77,7^{0}$ dan pada proyeksi mortise $79,9^{0} .8$ Penelitian yang dilakukan Shisirkumar mendapatkan tidak terdapat perbedaan talocrural angel pada pria dan wanita. ${ }^{17}$

Pemendekan fibula selain dari talocrural angel dapat dinilai dari pengukuran lateral malleolar length. Pada penelitian ini didapatkan nilai lateral malleolar length pada proyeksi anteroposterior $25,71 \pm 2,83 \mathrm{~mm}$ dan pada proyeksi mortise $26,70 \pm 3,40 \mathrm{~mm}$, serta terdapat perbedaan yang bermakna secara statistik antara pria dan wanita. Hasil penelitian ini hampir sama dengan penelitian Patil dkk pada populasi orang India, dimana didapatkan nilai lateral malleolar length proyeksi anteroposterior $27,35 \mathrm{~mm}$ dan proyeksi mortise $26,5 \mathrm{~mm} .{ }^{8}$ Nilai ini lebih kecil dari hasil penelitian Fessy dkk pada populasi orang Prancis, dimana didapatkan nilai lateral malleolar length 29,1 $\pm 2,5 \mathrm{~mm}$ (disitasi dari Rukavina, 1998). ${ }^{18}$

Pada penelitian ini didapatkan nilai medial malleolar length proyeksi anteroposterior $13,88 \pm 1,99 \mathrm{~mm}$ dan proyeksi mortise $14,03 \pm 1,6 \mathrm{~mm}$, serta terdapat perbedaan bermakna antara pria dan wanita. Hasil ini sama dengan penelitian Fessy dkk pada orang Perancis yang mendapatkan nilai medial malleolar length 13,1 $\pm 1,8 \mathrm{~mm}$ (disitasi dari Rukavina, 1998). ${ }^{18}$ Nilai ini lebih kecil dibanding hasil penelitian Patil dkk pada orang India yang mendapatkan nilai medial malleolar length proyeksi anteroposterior $15,3 \mathrm{~mm}$ dan proyeksi mortise $15,3 \mathrm{~mm} .{ }^{8}$ Penelitian antropometri tentang panjang malleolus medial masih kurang, padahal panjang malleolus medial berguna untuk mengukur talocrural angle pada pasien dengan fraktur bimalleolar. Peranjakan vertikal malleolus medial, khususnya pada pasien dengan fraktur vertikal malleolus medial atau pada fraktur comminuted malleolus medial tidak hanya akan mempengaruhi nilai talocrural angle tapi juga merupakan faktor prognosis yang jelek untuk hasil pengobatan (disitasi dari Rukavina, 1998). ${ }^{18}$

Pada penelitian ini didapatkan nilai tibiofibular overlap pada proyeksi anteroposterior $7,51 \pm 2,64 \mathrm{~mm}$ dengan rentang 2,69-13,41 mm dan pada proyeksi mortise $4,71 \pm 2,45 \mathrm{~mm}$ dengan rentang $0,00-9,31 \mathrm{~mm}$, serta terdapat perbedaan yang bermakna secara statistik antara pria dan wanita. Penelitian yang dilakukan Shisirkumar menyimpulkan tidak terdapat perbedaan tibiofibular overlap pada pria dan wanita. ${ }^{17}$ Nilai ini lebih kecil dari hasil penelitian Patil dkk yang mendapatkan nilai tibio-fibular overlap proyeksi anteroposterior 11,2 $\mathrm{mm}$ dan proyeksi mortise 4,2 $\mathrm{mm}^{8}$ Penelitian Shishirkumar mendapatkan nilai tibiofibular overlap 10,67mm. ${ }^{17}$ Kegunaan klinis tibiofibular overlap adalah untuk memprediksi cedera pada syndesmosis akibat fraktur atau cedera ligament. Pneumaticos dkk mengatakan tibiofibular overlap selalu ada disetiap pemeriksaan $x$-ray pergelangan kaki, namun apabila tibiofibular overlap tidak ditemukan maka kemungkinan terdapat cedera pada syndesmosis dan diperlukan fiksasi pada syndesmosis (disitasi dari Sowman, 2012). ${ }^{19}$ Sowman dkk dalam penelitiannya menemukan adanya variasi anatomi normal dimana tidak 
terdapatnya tibiofibular overlap tanpa adanya cedera pada syndesmosis, dimana dari 324 pasien yang ditelitinya ditemukan 4 pasien $(1,23 \%)$ tidak terdapat tibiofibular overlap. ${ }^{19}$ Pada penelitan ini ditemukan satu subjek yang tidak memiliki tibiofibular overlap tanpa adanya cedera pada syndesmosis. Pemeriksaan yang lebih baik untuk menentukan cedera syndesmosis adalah dengan pemeriksaan $\mathrm{MRI}$, namun pemeriksaan ini tidak tersedia disemua fasilitas kesehatan dan memerlukan biaya yang lebih tinggi.

Kegunaan klinis tibiofibular clear space adalah untuk memprediksi cedera pada syndesmosis akibat fraktur atau cedera ligament. Apabila tibiofibular clear space besar dari $6 \mathrm{~mm}$ maka kemungkinan terdapat cedera pada syndesmosis. ${ }^{7}$ Jenkinson dkk mengatakan peningkatan tibiofibular clear space lebih dari $1 \mathrm{~mm}$ merupakan indikasi untuk dilakukan stabilisasi pada syndesmosis. Penelitian Leeds dkk menyimpulkan peningkatan tibiofibular clear space $2 \mathrm{~mm}$ merupakan indikasi untuk dilakukan stabilisasi syndesmosis (disitasi dari Patil dkk, 2012). Pada penelitian ini didapatkan nilai tibiofibular clear space pada proyeksi anteroposterior $3,64 \pm 1,18 \mathrm{~mm}$ dan proyeksi mortise $3,85 \pm 1,09 \mathrm{~mm}$, serta tidak terdapat perbedaan yang bermakna antara pria dan wanita. Hasil ini lebih besar dari hasil penelitian Patil dkk yang mendapatkan nilai tibiofibular clear space proyeksi anteroposterior $2,4 \mathrm{~mm}$ dan lebih kecil pada proyeksi mortise $4,5 \mathrm{~mm} .^{8}$

Talar tilt adalah sudut yang dibentuk oleh garis permukaan sendi talus dengan garis permukaan sendi tibial plafond. Nilai normal talar tilt $0^{0} \pm 1,5^{0}$. Melebarnya sudut ini menandakan pergeseran talus dari tibia. ${ }^{20}$ Pada penelitian ini didapatkan semua sampel memiliki nilai talar tilt dalam range normal, dimana nilai talar tilt pada proyeksi anteroposterior $0,14^{0} \pm 0,10^{\circ}$ dan pada proyeksi mortise $0,19^{\circ} \pm 0,15^{\circ}$, serta tidak terdapat perbedaan yang bermakna antara pria dan wanita.

Pada penelitian ini didapatkan nilai medial clear space pada proyeksi mortise $2,97 \pm 0,75 \mathrm{~mm}$ dengan range 1,73-5,20mm. Hasil ini lebih besar dibanding penelitian Goker dkk di Turki yang mendapatkan ukuran medial clear space sendi pergelangan kaki kanan $2,56 \pm 0,50 \mathrm{~mm}$ dan $2,55 \pm 0,48 \mathrm{~mm}$ pada sendi pergelangan kaki kiri. ${ }^{9}$ Namun hasil penelitian ini lebih kecil dibanding hasil penelitian Joshua dkk di Amerika Serikat yang mendapatkan ukuran medial clear space sendi pergelangan

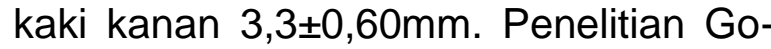
ker dan Joshua menemukan medial clear space pada pria lebih lebar dibanding wanita (disitasi dari Goker dkk, 2009). ${ }^{9}$ Berbeda dengan penelitian Goker dan Joshua, penelitian ini menyimpulkan tidak terdapat perbedaan bermakna antara pria dan wanita.

Medial clear space berguna untuk melihat adanya cedera pada ligamentum deltoid. Hal ini sesuai dengan hasil penelitian Hermans dkk yang menyimpulkan terdapat korelasi antara medial clear space dengan kelainan pada ligamentum deltoid. ${ }^{7}$ Koval dkk menyatakan apabila medial clear space lebih besar dari $5 \mathrm{~mm}$ dicurigai adanya cedera pada ligamentum deltoid. Sumber lain menyatakan apabila medial clear space besar dari $4 \mathrm{~mm}$ dicurigai adanya cedera pada ligamentum deltoid (disitasi dari Herman dkk, 2012). ${ }^{7}$ Namun menurut Joshua dkk ukuran medial clear space 
yang menentukan cedera ligamentum deltoid tergantung ukuran individu masing-masing. Pemeriksaan yang lebih baik untuk menentukan cedera ligamentum deltoid adalah dengan pemeriksaan MRI, namun pemeriksaan ini tidak tersedia disemua fasilitas kesehatan serta memerlukan biaya yang lebih tinggi (disitasi dari Goker dkk, 2009). ${ }^{9}$

Johnson angle adalah sudut antara permukaan sendi tibial plafond dengan sumbu panjang tibia. Sudut ini digunakan untuk melihat kemiringan permukaan sendi talokrural dengan sumbu panjang tibia dari anterior. Pada penelitian ini didapatkan nilai Johnson Angle pada proyeksi anteroposterior $87,77^{0} \pm 1,71^{\circ}$ dan pada proyeksi mortise $87,57^{0} \pm 1,84^{\circ}$, serta terdapat perbedaan yang bermakna antara pria dan wanita. Hasil ini hampir sama dengan hasil penelitian Isman di Amerika Serikat yang mendapatkan nilai normal Johnson Angle $85^{\circ} \pm 5^{0}$ dengan range $75^{\circ}$ sampai $96^{0} .14$

Pada penelitian ini didapatkan nilai anteroposterior inclination angle pada proyeksi lateral $7,47^{\circ} \pm 2,70^{\circ}$, dan terdapat perbedaan yang bermakna antara pria dan wanita. Hasil penelitian ini lebih besar dari hasil Stagni dkk yang mendapatkan nilai normal anteroposterior inclination angle pada populasi bangsa Eropa $5,0^{0} \pm 3,4^{0}$ (disitasi dari Kwon dkk, 2014) ${ }^{10}$, dan lebih kecil dibanding hasil penelitian Kwon pada populasi Korea dengan nilai $8,2^{0} \pm 3,2^{0} .{ }^{10}$

Anteroposterior gap digunakan untuk melihat peranjakan pada malleolus posterior. Stagni dkk mendapatkan nilai normal anteroposterior gap pada populasi bangsa Eropa 2,7 $\pm 1,8 \mathrm{~mm}$ (disitasi dari Kwon dkk, 2014) ${ }^{10}$, sedangkan Kwon dkk mendapatkan nilai normal populasi Korea lebih besar yaitu $4,2 \pm 1,7 \mathrm{~mm} .{ }^{10}$ Pada penelitian ini didapatkan nilai anteroposterior gap pada proyeksi lateral $3,50^{\circ} \pm 1,43^{\circ}$, serta terdapat perbedaan yang bermakna antara pria dan wanita.

Anterior distal tibia angle digunakan untuk melihat kemiringan permukaan sendi talokrural dengan sumbu panjang tibia dari anterior. Pada penelitian ini didapatkan nilai anterior distal tibia angle pada proyeksi lateral $82,53^{\circ} \pm$ $2,70^{\circ}$, serta terdapat perbedaan yang bermakna antara pria dan wanita. Hasil ini hampir sama dengan penelitian Mendicino dkk yang mendapatkan nilai anterior distal tibia angle pada populasi bangsa Eropa $80^{\circ} \pm 3^{0}$ (disitasi dari Kwon dkk, 2014). ${ }^{10}$

\section{SIMPULAN}

Nilai rerata $\mathrm{ROM}$ plantarfleksi $48,92^{0} \pm 5,82^{0}$, dorsofleksi $31,30^{\circ} \pm 4,07^{0}$, inversi $10,32^{0} \pm 2,28^{\circ}$, dan eversi $5,94^{\circ} \pm 1,20^{\circ}$. Nilai rerata talocrural angel proyeksi anteroposterior $76,53^{\circ} \pm 2,53^{\circ}$ dan proyeksi mortise $77,38^{\circ} \pm 2,27^{\circ}$, tibiofibular overlap proyeksi anteroposterior $7,51 \pm 2,64 \mathrm{~mm}$ dan proyeksi mortise 4,71 $\pm 2,45 \mathrm{~mm}$, tibiofibular clear space proyeksi anteroposterior 3,64 $\pm 1,18 \mathrm{~mm}$ dan proyeksi mortise 3,85 $\pm 1,09 \mathrm{~mm}$, talar tilt proyeksi anteroposterior $0,14^{\circ}$ $\pm 0,10^{\circ}$ dan proyeksi mortise $0,19^{\circ} \pm 0,15^{\circ}$, medial malleolar length proyeksi anteroposterior $13,88 \pm 1,99 \mathrm{~mm}$ dan proyeksi mortise $14,03 \pm 1,69 \mathrm{~mm}$, lateral malleolar

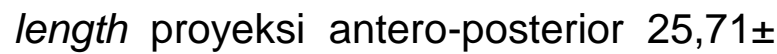

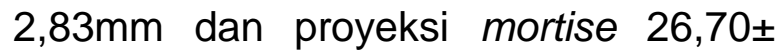
$3,40 \mathrm{~mm}$, johnson angle proyeksi anteroposterior $87,77^{0} \pm 1,71^{\circ}$ dan proyeksi mortise $87,57^{0} \pm 1,84^{\circ}$, medial clear space $2,97 \pm 0,75 \mathrm{~mm}$, anteroposterior inclination 
angle $7,47^{\circ} \pm 2,70^{\circ}$, anterior distal tibial angle $82,53^{\circ} \pm 2,70^{\circ}$, dan anteroposterior

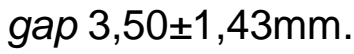

Didapatkan perbedaan yang bermakna antara pria dan wanita dalam hal ukuran tibiofibular overlap, medial malleolar length, lateral malleolar length, johnson angle, anteroposterior inclination

\section{DAFTAR RUJUKAN}

1. Panero J. Dimensi Manusia dan Ruang Interior: Buku Panduan untuk Standar Pedoman Perancangan. Jakarta: Erlangga, 2003.

2. Siniarska A, Wolanski N. Ethnic differences in body proportions, genes or environment? J Hum Ecol. 2002;13(5):337-43.

3. Rahmadian R. Penanganan awal cedera olahraga dalam penatalaksanaan orthopedi terkini untuk dokter layanan primer. Edisi 1. Jakarta: Mitra Wacana Media, 2014.

4. Hertel J. Functional anatomy, pathomechanics, and pathophysiology of lateral ankle instability. J Athl Train. 2002;37(4);364-75.

5. Drake RL, Vogl W, Mitchell A. Gray's anatomy for student. Elsevier, 2007.

6. Gilsans V, Ratib O. Hand bone age: a digital atlas of skeletal maturity. Los Angeles: Springer; 2005.

7. Hermans JJ, Wentink N, Beumer A, Hop WCJ, Heijboer MP, Moonen AFCM, et al. Correlation between radiological assesment of acute ankle fractures and syndesmotic injury on MRI. Skeletal Radiol. 2012;41:787801.

8. Patil MS, Raza SMG, Ali N. Anthropometric measurements of ankle mortise for evaluating mortise fracture reductions with an aim to develop contoured implants. Al Ameen J Med. 2012;5(4):381-7.

9. Goker B, Gomen E, Demirag M, Block JA. Quantification of the radiographic joint space width of the ankle. Clin Orthop and Relat Res. 2009;467:2083-9.

10.Kwon DG, Sung KH, Chung CY, Lee SH, Kim $\mathrm{TW}$, Lee $\mathrm{JH}$, et al. Preliminary finding of morphometric analysis of ankle joint in Korea Population. J Foot Ankle Surg;2014.53:3-7.

11.Kuo C, Lee G, Chang C, Hsu H, Leardini A, $\mathrm{Lu} \mathrm{T}$. Ankle morphometry in the Chinese angle, anterior distal tibial angle, dan anteroposterior gap.

Tidak didapatkan perbedaan yang bermakna antara pria dan wanita dalam hal ukuran dorsofleksi, plantarfleksi, eversi, inversi talocrural angel, tibiofibular clear space, medial clear space dan talar tilt.

Population. J Foot Ankle Res. 2008;1(suppl 1):011.

12.Norkin C, White J. Measurement of Joint Motion A Guide to Goniometry $4^{\text {th }}$ edition. The Ankle and Foot. Philadelphia: E.A. Davis Company;2009.

13.Johanson M, Baer J, Hovermale $H$, Phouthavong P. Subtalar joint position during gastrocnemius stretching and ankle dorsiflexion range of motion. $J$ Athl Train.2008;43:172-8.

14. Isman RE, Inman VT. Anthropometric studies of the human foot and ankle. Buletin of Prosthetics Research. 1969;97-129.

15. Magid D, Michelson J, Ney D, et al. Adult ankle fractures: comparison of plain films and interactive two and three-dimensional CT scans. Am J Roengtgenol. 1990;154:101723.

16. Rolfe B, Nordt W, Sallis JG, Distefano M. Assesing fibular length using bimalleolar angular measurements. Foot Ankle.1989;10: 104-9.

17.Shishirkumar, Nambiar S. Antropometric analysis of talocrural joint based on radiological study in south indian population. IJSR.2014;3(7).

18. Rukavina, A. The role of fibular length and the width of ankle mortise in post-traumatic osteoarthrosis after malleolar fracture. Int Orthop.1998; 22:357-60.

19.Sowman B, Radic R, Kuster M, Yates P, Breidiel B, Karamfilef $S$. Distal tibiofibular radiological overlap. Bone Joint Res. 2012; $1: 20-4$.

20. Anwar R, Tuson K, Khan SA. Classification and diagnosis in orthopae-dic trauma. New York: Cambridge University Press;2008: 194200. 